\title{
Population Pharmacokinetic Modeling of Flurbiprofen, the Active Metabolite of Flurbiprofen Axetil, in Chinese Patients with Postoperative Pain [Corrigendum]
}

\author{
Zhang J, Zhang H, Zhao L, Gu J, Feng Y, An H. J Pain \\ Res. 2018;11:3061-3070.
}

Correction for "Population pharmacokinetic modeling of flurbiprofen, the active metabolite of flurbiprofen axetil, in Chinese patients with postoperative pain" Zhang J, Zhang H, Zhao L, Gu J, Feng Y, An H. Journal of Pain Research. 2018;11:3061-3070.

The above article published in the Journal of Pain Research was under investigation for allegedly reporting results from an unrelated study using an unrelated clinical trial registration (CTR) number. We previously published an Expression of Concern to highlight this to readers while we completed our investigation:

Zhang J, Zhang H, Zhao L, Gu J, Feng Y, An H. Journal of Pain Research. 2019;12:2799. https://doi.org/10.2147/JPR. $\underline{\mathrm{S} 231531 .}$

The investigation has now been completed and determined that the study described in the published article was not a clinical trial and the CTR number (ChiCTR-TRC -11001791) provided in the article was used in error by the authors. Considering this finding the following correction to the article needs to be made:

- On page 3062, Methods section, 3rd sentence "The study was approved by the Medical Ethics Committee of Peking University People's Hospital (ChiCTR-TRC11001791) and conformed to the ethical principles of the Declaration of Helsinki." should read "The study was approved by the Medical Ethics Committee of Peking University People's Hospital (Ethics Approval No. 2010-30) and conformed to the ethical principles of the Declaration of Helsinki".

All relevant study data and ethical approval documents were reviewed and verified by the authors' institution.

The Expression of Concern also raised potential issues relating to data integrity and similarities between the present publication and an article published previously in Chinese Journal of Anesthesiology. These issues have also been resolved and together with the above correction the journal wishes to note all previous concerns raised in the Expression of Concern have now been resolved.

\section{Publish your work in this journal}

The Journal of Pain Research is an international, peer reviewed, open access, online journal that welcomes laboratory and clinical findings in the fields of pain research and the prevention and management of pain. Original research, reviews, symposium reports, hypothesis formation and commentaries are all considered for publication. The manuscript management system is completely online and includes a very quick and fair peer-review system, which is all easy to use. Visit http:// www.dovepress.com/testimonials.php to read real quotes from published authors. 